\title{
The triumvirate: why hypertension, obesity, and diabetes are risk factors for adverse effects in patients with COVID-19
}

\author{
Harsh Shah ${ }^{1} \cdot$ Md Shahjalal Hossain Khan ${ }^{1} \cdot$ Nikhil V. Dhurandhar $^{1} \cdot$ Vijay Hegde $^{1}[$
}

Received: 10 August 2020 / Accepted: 7 November 2020 / Published online: 15 February 2021

C) Springer-Verlag Italia S.r.l., part of Springer Nature 2021

\begin{abstract}
The outbreak of coronavirus disease 2019 (COVID-19) caused by a novel coronavirus, severe acute respiratory syndrome coronavirus 2 (SARS-CoV-2), has become a pandemic. The cellular receptor for SARS-CoV-2 entry is the angiotensinconverting enzyme 2, a membrane-bound homolog of angiotensin-converting enzyme. Henceforth, this has brought the attention of the scientific community to study the interaction between COVID-19 and the renin-angiotensin system (RAS), as well as RAS inhibitors. However, these inhibitors are commonly used to treat hypertension, chronic kidney disorder, and diabetes. Obesity is a known risk factor for heart disease, diabetes, and hypertension, whereas diabetes and hypertension may be indirectly related to each other through the effects of obesity. Furthermore, people with hypertension, obesity, diabetes, and other related complications like cardiovascular and kidney diseases have a higher risk of severe COVID-19 infection than the general population and usually exhibit poor prognosis. This severity could be due to systemic inflammation and compromised immune response and RAS associated with these comorbid conditions. Therefore, there is an urgent need to develop evidence-based treatment methods that do not affect the severity of COVID-19 infection and effectively manage these chronic diseases in people with COVID-19.
\end{abstract}

Keywords SARS-CoV-2 $\cdot$ Viral infection $\cdot$ Comorbidities $\cdot$ ACE2

\section{Introduction}

In December 2019, a new coronavirus (2019-nCoV) causing severe acute respiratory syndrome (SARS-CoV-2) was reported in Wuhan, China, and the world has witnessed a subsequent outbreak of this disease, known as COVID-19 (Coronavirus Disease 2019). By January 30, 2020, a transition of this localized outbreak led the World Health Organization (WHO) to declare it as public health emergency of national concern (PHEIC) and later as a pandemic by March 11, 2020. As of August 5, 2020 [1], there have been over

Managed by Massimo Federici.

Electronic supplementary material The online version of this article (https://doi.org/10.1007/s00592-020-01636-z) contains supplementary material, which is available to authorized users.

Vijay Hegde

vijay.hegde@ttu.edu

1 Obesity and Metabolic Health Laboratory, Department of Nutritional Sciences, Texas Tech University, 1301 Akron Ave, Lubbock, TX 79409, USA
$18,000,000$ of total confirmed cases of infection and more than 700,000 deaths due to COVID-19 worldwide. Countries around the world are suffering from an unprecedented burden to health care and the overall economy. COVID-19 manifestations range from asymptomatic to severe or critical type with the need for hospitalization or intensive care unit (ICU) [2, 3]. The common clinical features include fever and respiratory symptoms like cough, dyspnea [4, 5], and in severe cases, sepsis, multiple organ dysfunction including cardiac injury or kidney failure can develop [3, 6]. Clinical data have suggested a correlation between the severity of COVID-19 infection outcome with advanced age and several comorbidities including hypertension, obesity, and diabetes [5, 7-9]. The severity of complications and a need for hospitalization are more when COVID-19 infection is associated with underlying comorbid complications [5, 7, 9-11]. The prevalence of hypertension, obesity, and diabetes among hospitalized COVID-19 patients is much more than nonhospitalized COVID-19 patients [9, 12]. Hypertension, obesity, and diabetes are closely linked to each other, and these comorbidities are associated with an elevated risk of recurrent infection due to underlying impairments in the host 
defense system [13]. As an efficient and integrated immune defense system is necessary for the body's response to infection, a compromised immune response makes the host more vulnerable to infection and related severe complications.

This review is aimed at highlighting why conditions of hypertension, obesity, and diabetes increase the risk for infections, and more particularly how preexistence of these metabolic diseases in patients with COVID-19 causes severe manifestations and clinical outcomes. The available information about this novel COVID-19 pandemic is based on limited clinical data and information from similar previous infections including H1N1 influenza, severe acute respiratory syndrome-coronavirus (SARS-CoV), and Middle East respiratory syndrome (MERS). Currently, there are no vaccines or reliable treatments available for the prevention or treatment for CoV-2 infection; therefore, it is important to understand its mechanism of infection and higher risk among individuals with obesity, diabetes, and hypertension to possibly reduce the morbidity and associated mortality.

\section{Hypertension, obesity, and diabetes: coexistence of the triumvirate with an increased risk for respiratory infections}

The rising prevalence and disease burden of obesity have received significant attention globally over the past three decades. Many epidemiological studies have suggested a high body mass index (BMI) as a risk factor for many chronic diseases, including diabetes, cardiovascular disease (CVD), chronic kidney disease, hypertension, and infections. Hypertension, obesity, and diabetes are interconnected with an elevated risk of renal complications and cardiovascular diseases, and the coexistence of these diseases increases the disease-associated mortality. Considering the multifactorial and complex nature of these conditions, including the combination of environmental, genetic, behavioral, and lifestylerelated factors, we are yet to clarify all driving forces linking this triumvirate [14].

Viral infections including H1N1 influenza, SARS-CoV (severe acute respiratory syndrome-coronavirus) and MERS$\mathrm{CoV}$ (middle eastern respiratory syndrome-coronavirus) cause respiratory infections, and the coexistence of various comorbidities like hypertension, obesity, and diabetes has been linked with severe illness among these patients. SARS-CoV and MERS-CoV were first reported in 2002 and 2012, respectively $[15,16]$. Hyperglycemia and known history of diabetes were reported as an independent predictor of mortality and morbidity among SARS patients [17]. Similarly, systemic analysis of MERS-CoV infection cases showed that diabetes and hypertension were equally prevalent in $50 \%$ of patients and obesity was prevalent in $16 \%$ of the patients. Additionally, these underlying comorbidities were found to be associated with severe illness and mortality in MERS-CoV patients [18]. In 2008-09, H1N1 influenza A virus transmitted from swine to human, later developing into a human to human transmission, caused a pandemic and is currently the predominant strain for seasonal human influenza [19]. During the influenza viral infection, the presence of obesity and related comorbidities showed an increased incidence of morbidity and mortality [20,21]. A systematic review and meta-analysis study showed the association between obesity with a higher risk of ICU admission and mortality among H1N1-infected patients [22]. Taken together, these data suggest that people with obesity are more susceptible to increased risk of influenza-related hospitalization, morbidity, and mortality.

Limited availability of clinical data about the outcomes of H1N1 infection in diabetes patients makes it nonconclusive [23-25]. A study conducted with non-Hispanic Black and White US adults, to assess the impact of diabetes in influenza-related mortality, found that irrespective of race, sex, or socioeconomic status, people with diabetes are more likely to have higher medical consultation, morbidity, mortality, and hospitalization compared to the nondiabetic subjects [26]. However, the worse outcomes among diabetes patients with $\mathrm{H} 1 \mathrm{~N} 1$ infection could be a consequence of related underlying comorbidities including obesity and cardiovascular diseases but not diabetes itself alone [27].

In hypertension, the increased sympathetic nervous system (SNS) activity and decreased parasympathetic nervous system (PNS) increase the blood pressure and promote activation of innate immunity via Toll-like receptors (TLRs), which can induce oxidative stress and inflammation. These events promote disease progression and lead to organ damage [28]. Obesity is associated with low-grade systemic inflammation which leads to elevated circulatory proinflammatory cytokines [29]. Excessive overload of nutrients induces oxidative stress, increases infiltration of macrophages, and further leads to activation of inflammatory processes [30-32]. Moreover, in diabetes condition, immune response to infection is compromised [33]. Impaired glycemic control is also associated with alteration in various immune mechanisms against viral infections [34]. Therefore, the compromised host immune defense makes them vulnerable to infection. The increased incidence of morbidity and mortality with respiratory infections in the presence of obesity and related comorbidities suggests possible similar risks of severe outcomes for individuals with these underlying conditions during the current global pandemic with the novel SARS-CoV-2 virus. 


\section{SARS-CoV-2 infection and COVID-19}

SARS-CoV-2 and SARS-CoV both belong to subgenus Sarbecovirus, genus Betacoronavirus, and family Coronaviridae [35]. The SARS-CoV was reported for the first time over 17 years ago in Guangdong Province, China [36], which was also responsible for causing a new disease called Severe Acute respiratory syndrome (SARS). SARS-CoV infected 8098 individuals and caused 774 deaths in 29 countries [37]. Similarly, A novel coronavirus (SARS-CoV-2) has emerged with effective human-to-human transmission and leading to pneumonia-like outbreak first reported in December 2019 in Wuhan, China [38, 39]. Both viruses can lead to life-threatening respiratory illnesses in humans.

Genomic characterization revealed around 80 percent similarity between SARS-CoV-2 and SARS-CoV [40]. Moreover, protein sequence analysis showed that both viruses share the same seven conserved nonstructural domains suggesting a relationship between these two coronaviruses [40]. The entry of coronavirus in the cell is complex. The first step in the entry process, the virus-cell fusion, requires receptor binding and proteolysis of the receptor-binding domain (RBD). Structural proteins of $\mathrm{CoV}$ are classified into four categories of proteins, which include nucleocapsid $(N)$, envelope $(E)$, membrane $(M)$, and spike $(S)$ proteins [41]. Ectodomain segment of spike consists of a receptor-binding subunit $\mathrm{S} 1$ and membrane-binding subunit S2, which together are needed for virus entry to allow viral genome to enter the cell [42-44]. Membrane fusion and binding of receptors are crucial steps for coronavirus infection. Biochemical [45, 46] and structural studies [47-49] showed that the RBD of SARS-CoV-2 interacts with ACE2 for cellular entry, similar to SARS-CoV [50, 51]. The binding affinity of $S$ protein of virus and ACE2 appeared to be a major determinant for virus replication rate and severity of the disease [42, 46, 52]. However, RBD of SARS-CoV-2 is less exposed and has a higher affinity for its human ACE2 (hACE2) receptor compared to the RBD of SARS-CoV, suggesting efficient immune surveillance evasion and cellular entry, respectively [53]. Additionally, Priming of S protein and proteolytic cleavage of a spike by TMPRSS2, a Serine protease, and Furin, a proprotein convertase are required for the membrane fusion and subsequent viral entry via the endosomal pathway [42, 43]. After entry, the virus multiplies, and mature virions are transported to the cell surface and released via exocytosis (Fig. 1).

\section{COVID-19 and comorbidities}

Due to the lack of a well-designed cohort study for COVID19 in patients with various comorbidities like hypertension, obesity, and diabetes, it is not clear whether these comorbidities are risk factors for SARS-CoV-2 infections. However, currently available data indicate an association of these comorbidities with severe outcomes in patients with COVID-19 (See Table 1 for studies that show the effect of comorbidities like hypertension, obesity, and DM with SARS-CoV-2 infection).

\section{Hypertension}

Prevalence of hypertension in COVID-19 seems higher in patients with high severity, which includes the use of primary composite endpoint (i.e., intensive care unit, use of mechanical ventilation), ARDS, or death. Recently, Guan et al. [11] reported that $23.7 \%$ of subjects with hypertension as one of the coexisting illnesses had a more severe course of COVID-19 disease compared with $13.4 \%$ subjects, who had a nonsevere disease. Similarly, another study from China [10] showed that nearly $58 \%$ of COVID-19 patients who required intensive care had hypertension, whereas only $21.6 \%$ of total COVID-19 patients who did not require the use of ICU had hypertension. Two other studies $[4,54]$ also reported that $48 \%$ of COVID-19 patients who died had an underlying condition of hypertension. However, it is important to note that these associations did not account for age in the analysis and may be confounded by the higher incidence of hypertension in older people. As people age, they exhibit severity of disease including a high risk of acute respiratory distress syndrome (ARDS) and a high mortality rate compared to younger people [10, 54-57]. Hypertension may also present with other cardiovascular risk factors such as diabetes, hypertension-mediated heart damage, and other cardiovascular-related complications. These risk factors show an increasing prevalence with age [58]. This indicates that this association is possibly confounded by age and other comorbidities [59].

Control of blood pressure in patients with hypertension has been considered as one of the important concerns to lessen the disease burden regardless of its effect on SARSCoV-2 infection [60]. Besides, in COVID-19 patients with coexisting hypertension, high blood pressure was independently associated with hospitalization, mortality, and heart failure [61]. The mechanistic relationship between hypertension and COVID-19 may be explained by the use of ACE2 (angiotensin converting enzyme 2) as a receptor for SARSCoV-2 entry $[42,46]$. ACE2 is an important element of the RAS (renin-angiotensin system), which regulates vasodilation and vasoconstriction and thereby plays an essential role in the pathogenesis of hypertension [62]. In severe forms of hypertension, blood angiotensin II levels are high and significantly correlated with diastolic blood pressure [63]. Angiotensin II is an essential mediator of tissue inflammation by 


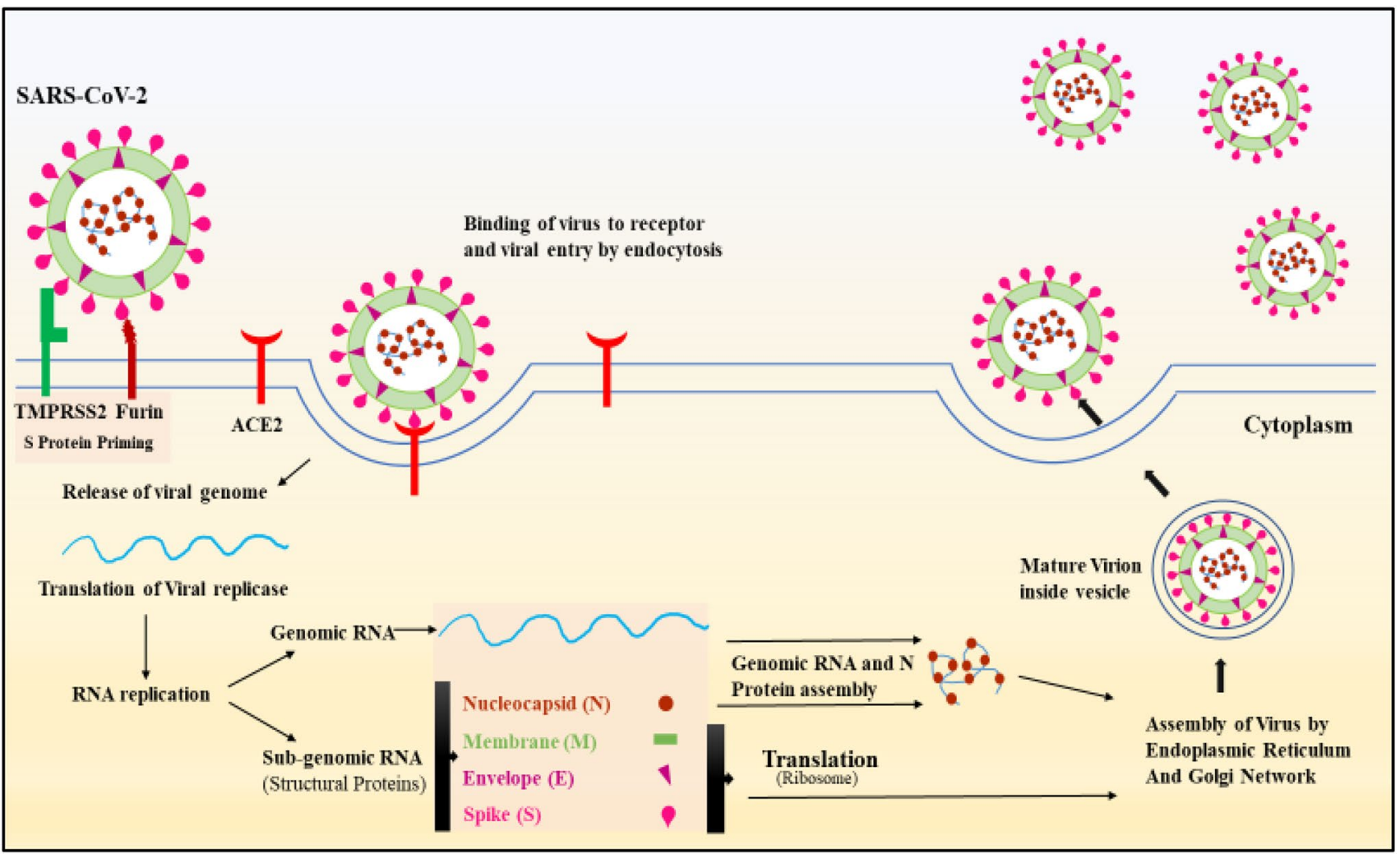

Fig. 1 Schematic diagram of SARS-CoV-2 infection cycle. S protein priming facilitates the binding of the virus with angiotensin converting enzyme-2 (ACE2) and thereby fusion of viral and cellular membrane occurs. This, in turn, releases a viral genome inside the cell. The next step is translation of the viral replicase gene followed by RNA replication to produce genomic RNA and subgenomic RNAs.

increasing vascular permeability, recruiting inflammatory cells, and oxidative stress [64, 65]. Angiotensin II has been shown to induce lung edemas, impaired lung function, and lung inflammation in pneumonia [66]. Moreover, the SARS spike protein binding to ACE2 showed elevated angiotensin II levels along with severe acid-induced pneumonia. This pathology was rescued by an angiotensin II type 1 receptor antagonist, losartan, suggesting the inflammatory role of angiotensin II [67]. ACE2 is a negative regulator of RAS that inactivates angiotensin II. Coronavirus infection causes downregulation of ACE2 [68], and probably, in the case of SARS-CoV-2, that may cause elevation of angiotensin II and tissue inflammation. Several reports suggested elevated levels of angiotensin II in COVID - 19 patients with high disease severity $[69,70]$. Altogether, these indicate that hypertensive individuals are more vulnerable to COVID-19 disease severity.

In early phase of COVID-19 pandemic, it was suggested that the use of RAS inhibitors (i.e., ACE inhibitors (ACEIs) and angiotensin II receptor blockers (ARBs)) may be detrimental to COVID-19 patients [71] as some experimental
Subgenomic RNAs are then translated into proteins, and genomic RNA is packaged with $\mathrm{N}$ proteins and along with all other structural proteins (i.e., N, E, S, M). The assembly of the virus occurs in various steps by Endoplasmic Reticulum and Golgi network. Mature virion inside the vesicle then released from the cell

studies suggested a compensatory increase in ACE2 upon the use of above-mentioned inhibitors [72-74]. A comprehensive review [75] on assessing the risk of RAS inhibitors in COVID-19 suggested inconsistency in the effect of ARB and ACEI on ACE2 expression in animals. However, human studies suggest no significant effect on ACE2 by RAS inhibitors. A study from NYU Langone system reported no significant increase in the propensity of detecting positive for SARS-CoV-2 infection or in the risk of severe infection correlated with various antihypertensive medications including ACEI and, ARB [76]. A retrospective cohort study from Denmark reported that prior use of ACEI or ARBs is neither associated with COVID-19 diagnosis nor with mortality or disease severity among patients with hypertension [77]. Another large population-based study from Italy suggested no association for the use of antihypertensive medications with the risk of developing COVID-19 and related severe outcomes [78]. Hence, although there is an underlying concern for the effect of RAS inhibitors on ACE2 and subsequent increase in susceptibility or severity of COVID-19 infection, there is no justification for the preemptive change 
Table 1 List of studies that show the effect of comorbidities like hypertension, diabetes, and obesity with SARS-CoV-2 infection

\begin{tabular}{|c|c|c|c|c|}
\hline \multirow{3}{*}{$\begin{array}{l}\text { Study Details } \\
\text { [Authors, Country] }\end{array}$} & \multicolumn{3}{|l|}{ Comorbidities } & \multirow[t]{3}{*}{${ }^{*} p$ values } \\
\hline & $\begin{array}{l}\text { Hypertension (HT) } \\
\mathrm{n} / \mathrm{N}(\%)\end{array}$ & $\begin{array}{l}\text { Diabetes } \\
(\mathrm{Db}) \\
\mathrm{n} / \mathrm{N}(\%)\end{array}$ & $\begin{array}{l}\text { Obesity } \\
\text { (Ob) } \\
\mathrm{n} / \mathrm{N}(\%)\end{array}$ & \\
\hline & \multicolumn{3}{|c|}{ [Use of ICU or Disease Severity or Survival—n/N (\%)]* } & \\
\hline $\begin{array}{l}\text { Chen et al. [4] } \\
\text { China }\end{array}$ & $\begin{array}{l}93 / 274(34 \%) \\
{[\text { Survivor-39/161 (24\%) }} \\
\text { Non-Survivor -54/113 (48\%)] }\end{array}$ & $\begin{array}{l}47 / 274(17 \%) \\
{[\text { Survivor-24/161 }(21 \%)} \\
\text { Non-Survivor-23/113(14\%)] }\end{array}$ & NR & NR \\
\hline Huang et al. [5] China & $\begin{array}{l}6 / 41(15 \%) \\
{[\text { ICU-2/6 }(33.3 \%)} \\
\text { Non-ICU-4/6 }(0.67 \%)]\end{array}$ & $\begin{array}{l}8 / 41(20 \%) \\
{[\text { ICU-1/8 }(0.13 \%)} \\
\text { Non-ICU-7 /8 }(0.88 \%)]\end{array}$ & NR & $\begin{array}{l}\mathrm{HT}-p=0.93 \\
\mathrm{Db}-p=0.16\end{array}$ \\
\hline $\begin{array}{l}\text { Richardson et al. [8] } \\
\text { USA }\end{array}$ & $3026(56.6 \%)^{\#}$ & $1808(33.8 \%)^{\#}$ & $1737 / 4170(41.7 \%)$ & NR \\
\hline $\begin{array}{l}\text { Petrilli et al. [9] } \\
\text { USA }\end{array}$ & $\begin{array}{l}2256 / 5279(42.7 \%) \\
{[\text { Not Hospitalized-557/2538 }} \\
\quad(21.9 \%) \\
\text { Hospitalized-1699/2741 (62\%)] }\end{array}$ & $\begin{array}{l}1195 / 5279(22.6 \%) \\
{[\text { Not Hospitalized-245/2538 }} \\
\quad(9.7 \%) \\
\text { Hospitalized—950/2741 (34.7\%)] }\end{array}$ & $\begin{array}{l}\text { 1865/5279 (35.3\%) } \\
\text { [Not Hospital- } \\
\text { ized-781/2538 } \\
(30.7 \%) \\
\text { Hospital- } \\
\text { ized-1084/2741 } \\
(39.5 \%)]\end{array}$ & $\mathrm{HT}, \mathrm{Db}, \mathrm{Ob}-p<0.001^{\$}$ \\
\hline $\begin{array}{l}\text { Wang et al. [10] } \\
\text { China }\end{array}$ & $\begin{array}{l}43 / 138(31.2 \%) \\
{[\text { ICU-21/36 }(58.3 \%)} \\
\text { Non-ICU-22/102 (21.6\%)] }\end{array}$ & $\begin{array}{l}14 / 138(10.1 \%) \\
{[\mathrm{ICU}-8 / 36(22.2 \%)} \\
\text { Non-ICU-6/102 (5.9\%)] }\end{array}$ & NR & $\begin{array}{l}\mathrm{HT}-p<0.001 \\
\mathrm{Db}-\mathrm{p}=0.009\end{array}$ \\
\hline $\begin{array}{l}\text { Guan et al. [11] } \\
\text { China }\end{array}$ & $\begin{array}{l}165 / 1099(15 \%) \\
{[\text { Severe-41/173 }(23.7 \%)} \\
\text { Non-severe-124/926 (13.4\%)] }\end{array}$ & $\begin{array}{l}81 / 1099(7.4 \%) \\
{[\text { Severe-28/173 (16.2\%) }} \\
\text { Non-severe-53/926 (5.7\%)] }\end{array}$ & NR & NR \\
\hline $\begin{array}{l}\text { Grassilli et al. [12] } \\
\text { Italy }\end{array}$ & $\begin{array}{l}509 / 1043(49 \%) \\
{[\text { Died-195/309 }(63 \%)} \\
\text { Discharged-84/212(40\%)] }\end{array}$ & $180 / 1591(17 \%)$ & NR & $\mathrm{HT}-p<0.001$ \\
\hline $\begin{array}{l}\text { Zhou et al. [54] } \\
\text { China }\end{array}$ & $\begin{array}{l}58 / 191(30 \%) \\
{[\text { Survivor-32/137 }(23 \%)} \\
\text { Non-survivor-26/54 (48\%)] }\end{array}$ & $\begin{array}{l}36 / 191(19 \%) \\
{[\text { Survivor-19/137 }(14 \%)} \\
\text { Non-survivor-17/54 (31\%)] }\end{array}$ & NR & $\begin{array}{l}\mathrm{HT}-p=0.0008 \\
\mathrm{Db}-p=0.0051\end{array}$ \\
\hline $\begin{array}{l}\text { Wu et al. [55] } \\
\text { China }\end{array}$ & $\begin{array}{l}39 / 201(19.4 \%) \\
{[\text { ARDS-23/84 }(27.4 \%)} \\
\text { No ARDS-16/117 (13.7\%)] }\end{array}$ & $\begin{array}{l}22 / 201(10.9 \%) \\
{[\text { ARDS-16/84 }(19 \%)} \\
\text { No ARDS-6/116(0.05\%)] }\end{array}$ & NR & $\begin{array}{l}\mathrm{HT}-p=0.02 \\
\mathrm{Db}-p=0.002\end{array}$ \\
\hline $\begin{array}{l}\text { Zhang et al. [56] } \\
\text { China }\end{array}$ & $\begin{array}{l}42 / 140(30 \%) \\
{[\text { Severe-22/58 }(37.9 \%)} \\
\text { Non-severe-20/82 (27.4\%)] }\end{array}$ & $\begin{array}{l}17 / 140(12.1 \%) \\
{[\text { Severe-8/58 }(13.8 \%)} \\
\text { Non-severe-9/82(11\%)] }\end{array}$ & NR & $\begin{array}{l}\mathrm{HT}-p=0.85 \\
\mathrm{Db}-p=0.615\end{array}$ \\
\hline $\begin{array}{l}\text { McMicheal et al. [57] } \\
\text { USA }\end{array}$ & $74 / 167(44.3 \%)$ & $38 / 167(22.8 \%)$ & $37 / 167(22.2 \%)$ & NR \\
\hline $\begin{array}{l}\text { Shi et al. [101] } \\
\text { China }\end{array}$ & $\begin{array}{l}127 / 416(31 \%) \\
\text { [With cardiac injury-49/82 } \\
(59.8 \%) \\
\text { Without cardiac injury-78/334 } \\
(23.4 \%) \text { ] }\end{array}$ & $\begin{array}{l}60 / 416(14.4 \%) \\
\text { [With cardiac injury-20/82 } \\
\quad(24.4 \%) \\
\text { Without cardiac injury }-40 / 334 \\
\quad(12 \%) \text { ] }\end{array}$ & NR & $\begin{array}{l}\mathrm{HT}-p<0.001 \\
\mathrm{Db}-p=0.008\end{array}$ \\
\hline $\begin{array}{l}\text { Bean et al. [102] } \\
\text { UK }\end{array}$ & $150 / 205(51.2 \%)$ & $62 / 205(30.2 \%)$ & NR & NR \\
\hline
\end{tabular}

$I C U$, intensive care unit, $A R D S$, acute respiratory distress syndrome, $N R$, not reported

${ }^{\#} N$ value is not reported

${ }_{p} p$ value for risk of hospitalization

in using these inhibitors in people who are at risk or having COVID-19 infection, unless clinically advised [79]. Many renowned societies including the European society of hypertension, American society of hypertension, and American heart association are in agreement with this position [59,
79, 80]. Though theoretically high expression of ACE2 may suggest high chances of infection, it is also important to note that viral entry requires proteolytic degradation by TMPRSS2 [42]. Hence, increased ACE2 expression may affect the tissues that coexpress both ACE2 and TMPRSS2. 
However, it is unknown whether only elevated ACE2 expression affects viral infection. Although all observational studies provide important assurance about the safety of RAS inhibitors during the COVID-19 pandemic, their confirmation in randomized controlled trials will provide a greater degree of assurance to patients and doctors.

\section{Obesity}

Several reports are suggesting an association between obesity and the severity of COVID-19 infection and mortality. Clinical data for COVID-19 infection from China found a $86 \%$ and $142 \%$ higher association for overweight and obesity, respectively, with high severity of infection compared to normal-weight individuals when adjusted for multiple potential confounders [81]. Another study from China showed increased odds of severe SARS-CoV-2 infection in obese patients [82]. A study from USA showed obesity as the second comorbidity (41.7\%) after hypertension (56.6\%) among hospitalized patients following COVID-19 infection [8]. Similarly, obesity was also the significant independent predictor of hospitalization, after old age, among over 5000 patients with COVID-19 infection in New York City [9]. Furthermore, a small study from France reported data from 124 patients with COVID-19, suggesting an association of the need for invasive mechanical ventilation with a $\mathrm{BMI} \geq 35 \mathrm{~kg} / \mathrm{m}^{2}$, independent of other comorbidities [83].

Certain underlying parameters may mediate this high risk, including various pathophysiological characteristics of obesity like impaired respiratory functions, declined respiratory muscle strength, and low lung capacity [84]. Transcriptomics data from the studies of mice with diet induced obesity indicate ACE2 upregulation in the lungs of obese mice compared to lean mice [85], which may promote $\mathrm{CoV}-2$ infection. Besides, adipose tissue in obese individuals may act as a reservoir for more extensive viral replication due to ACE2 expression. The higher amount of adipose tissue may lead to increased viral shedding and immune activation and subsequent severe complications [86]. Liraglutide, which is used to treat obesity [87], has also been shown to upregulate ACE2 expression in diabetic rats [88]. It remains to be determined whether using liraglutide as treatment during COVID-19 infection may be a concern. Moreover, obesity is also associated with a high risk for complications, development of ARDS, and need for hospitalization with the use of primary composite endpoint $[89,90]$. During obesity, angiotensin II and angiotensinogen are elevated [91, 92]. RAS activation and angiotensin II production are involved in obesity-associated inflammation [93, 94]. Higher expression of angiotensin II leads to inflammation and fibrosis in the lung, thereby enhancing lung injury and ARDS [95, 96].
Hence, obesity-associated inflammation and ARDS may even worsen COVID-19 disease severity.

On the contrary, research on how obesity can affect outcomes of critical illness is still controversial and some reports suggest an inverse relationship between obesity and mortality [97]. This is known as the obesity survival paradox. Additionally, mortality rates are less in obese patients with pneumonia [98]. This protection could be due to obesity-mediated low-grade inflammatory processes creating protective environment to limit a detrimental effect of second hit (e.g., infection), more aggressive medication, and some other unidentified factors [98, 99]. However, obesity is found to be associated with increased disease severity in COVID-19 patients. It is possible that limited available resources during this pandemic may limit early admission of these patients to intensive care for monitoring purposes [100]. Hence, healthcare personnel should consider taking preventive measure and extra care to avoid disease severity in obese individuals.

\section{Diabetes}

Diabetes, hypertension, obesity, and age are associated with a higher risk of morbidity and mortality among COVID-19 patients [5, 8-10, 38, 54-57, 83, 101, 102]. Diabetes was also considered as a major predictor of the severity of disease during the MERS-CoV [18]. Patients with SARS also showed a strong association with DM and blood glucose levels [103]. Likewise, blood glucose is represented as a predictor of severe outcomes and death in patients with COVID-19 [104]. Recently, a retrospective study from the USA with 451 patients of COVID-19 with diabetes and/or hyperglycemia reported that uncontrolled hyperglycemia is associated with longer hospital stay and higher mortality compared to people without diabetes or uncontrolled hyperglycemia [105]. Similarly, Zhu and colleagues [106] suggested that diabetes increased the requirement of medical interventions and mortality risk for COVID-19 infected patients. A meta-analysis reported higher mortality risk and higher risk of ICU admission in COVID-19-diagnosed patients with diabetes [107]. On the contrary, well-controlled diabetes is linked with improvement in outcomes for patients with COVID-19 [106]. Previously, hyperglycemia was considered to be the link for the association between diabetes and viral infections, which influences viral growth and inflammation, thereby exacerbating mortality and morbidity in patients [108]. Severe infections may cause difficulty in managing blood glucose levels. However, the causal relationship between control of glucose level and disease severity is yet to be established. 
There could be different mechanisms, which may favor COVID-19 infection in a patient with diabetes. The virus enters the cell via the ACE2 receptor, which is an important element of the system involved in blood pressure management and inflammation [42]. Various diabetic animal models have demonstrated an increased expression level of ACE2 in the pancreas, kidney, liver, and serum [109, 110]. Recently, a phenome-based mendelian randomization study on diabetes indicated that enhanced ACE2 expression in lungs may be causally linked with diseases or traits [111]. Insulin administration in nonobese diabetic (NOD) mice downregulates ACE2 expression in lungs [109], whereas pharmacological drugs for glycemic control like glucagon-like-peptide-1 (GLP-1) agonist (e.g., liraglutide), and Pioglitazone, upregulate ACE2 expression in lungs of STZ-induced diabetic rats and in insulin-sensitive tissues of high-fat diet-fed rats, respectively [88, 112]. In addition, elevated circulating furin, which is required for proteolytic cleavage of viral spike protein for cellular entry of COVID-19 [113], has been observed in patients with diabetes [114]. Delay in SARS-CoV-2 clearance was also reported in patients with diabetes [115]. A recent observational study with COVID-19 patients with diabetes suggests insulin infusion as an effective method to improve glycemic control and reduce disease severity [116]. Moreover, some metabolic complications of preexisting diabetes including ketoacidosis have been observed with COVID-19 patients [117-119]. Collectively, these studies support the hypothesis that patients with diabetes are at a higher risk of COVID-19 infection and severe outcomes.

Many leading diabetes researchers suggest a bidirectional relationship between COVID-19 and diabetes [120]. The ACE2 is expressed in key metabolic organs (i.e., muscle, liver, pancreas, and adipose tissue), which plays an important role in glucose homeostasis [121]. In vitro and humanized mice study suggests that human liver and pancreatic islets are highly permissive for SARS-CoV2 infection [122]. SARS-CoV infection damaged various metabolic organs including the endocrine part of pancreas and leads to acute insulin-dependent diabetes [123]. Similarly, few reports also indicate pancreatic injury in patients with COVID-19 [124-126]. However, careful investigation is needed to determine impairment of endocrine function of pancreas in COVID patients. Moreover, in COVID-19, elevated levels of inflammatory cytokines known as cytokine storm have been linked in multiorgan failure with severe disease condition [127]. Hence, it is possible that COVID-19 may cause impairment of insulin secretory function by damaging pancreas or by inflammation-induced acute insulin resistance to trigger pleiotropic effects that impairs glucose metabolism and exacerbate preexisting diabetes or may even cause transient diabetes.

\section{COVID-19 and other associated complications related to triumvirate}

Several reports indicated the threat of COVID-19 for patients with cardiovascular disease (CVD) and renal complications $[128,129]$ that are also associated with this triumvirate. Obesity is closely associated with CVD with a high propensity of mortality and morbidity [130]. Similarly, high blood pressure is one of the most critical risk factors for developing cardiovascular complications [131, 132]. Data of clinical studies indicate that outcomes of COVID-19 in CVD patients are linked with disease severity, and a high prevalence of preexisting CVD has been associated with mortality in COVID-19 patients [7, 133-138]. Also, several reports showed the development of cardiovascular disorders in COVID-19 patients [139-141]. These data suggest a bidirectional relationship between COVID-19 and cardiovascular diseases. There are two possible explanations for this relationship. First, induction of "cytokine storm" and elevated systemic inflammation in COVID-19 may accelerate the cardiovascular system's complications. A significant linear correlation between high troponin (a marker for myocardium injury) levels and C-reactive protein (an inflammatory marker) has been observed in COVID-19 patients [141], suggesting an association between inflammation and injury of the myocardium. Second, ACE2, a receptor for SARS$\mathrm{CoV}-2$, is a part of RAS that is involved in the maintenance of blood pressure. In COVID-19, elevated levels of angiotensin II have been observed [69, 70]. High levels of angiotensin II can elevate blood pressure and damage the myocardium by inducing acute ischemia, ventricular hypertrophy, oxidative stress, and proinflammatory cascade $[142,143]$ that may worsen cardiovascular complications in COVID-19 patients.

Patients with diabetes are vulnerable to infection due to impaired immune function [144]. It is estimated that 30-40\% of diabetes patients develop kidney infections. Also, diabetes kidney disease is associated with disease severity and mortality in diabetic patients [145]. Reports suggest that COVID-19 patients have a high incidence of kidney dysfunction (high levels of blood urea nitrogen (BUN), serum creatine, D-dimer), and acute kidney injury (AKI) $[128$, 146-148]. Also, AKI is associated with severe outcome and mortality in COVID-19 patients [147-150]. Kidney expresses ACE2 [151], and SARS-CoV-2 was detected in patients' urine and kidney samples [128]. Moreover, viral structure and protein and RNA of the SARS-CoV-2 are found in kidney of COVID-19 patients [152, 153]. This suggests that SARS-CoV-2 can directly damage the kidney. However, mechanism of kidney disease in COVID-19 patient requires further investigation. 


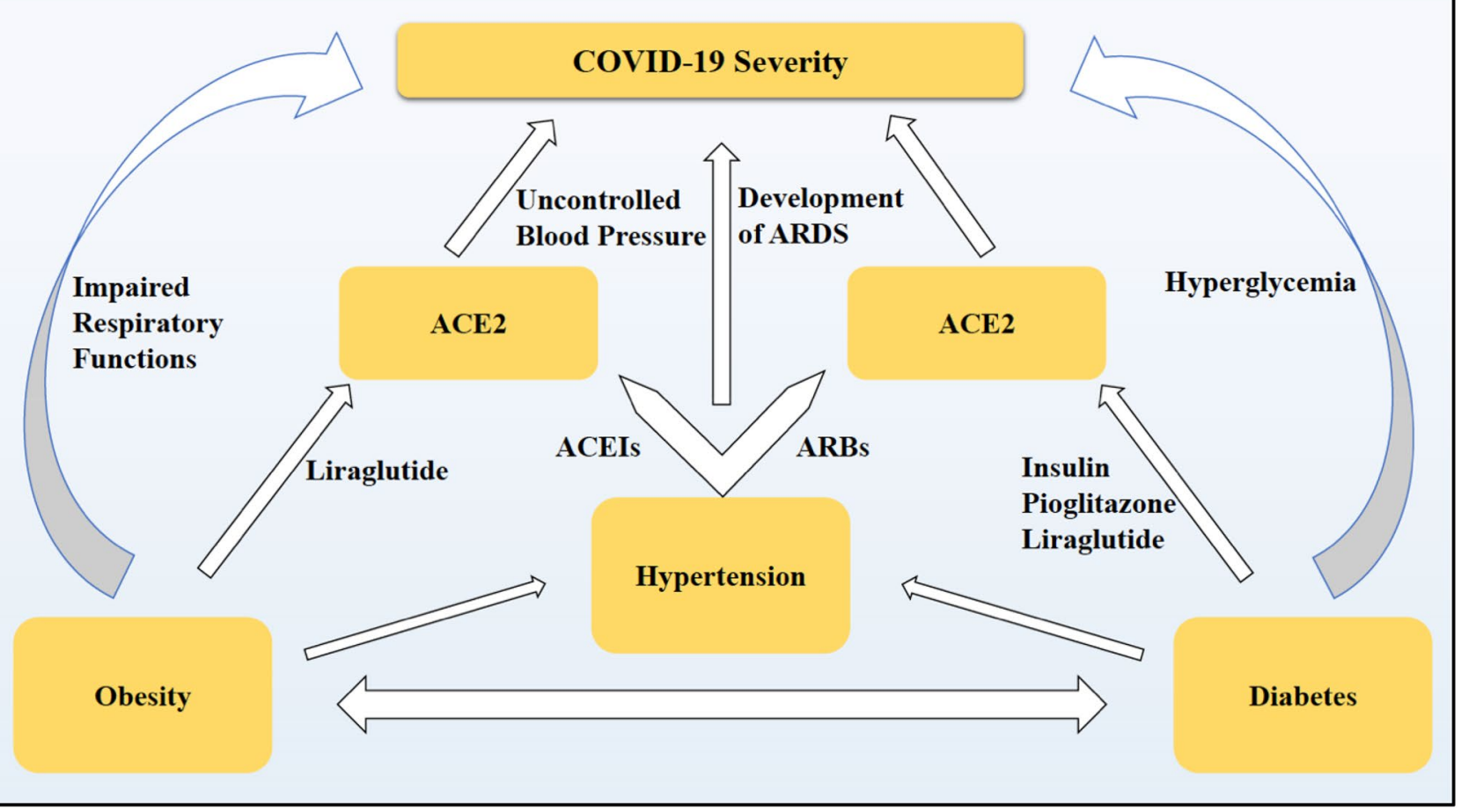

Fig. 2 Proposed mechanism of disease severity in COVID-19 patients with comorbidities like hypertension, obesity, and diabetes. Hypertension, obesity, and diabetes are associated with impaired respiratory functions, uncontrolled blood pressure and development of ARDS, and hyperglycemia, respectively, which in turn leads to increased disease burden in COVID-19 patients. Moreover, medications that are

\section{Conclusion and future directions}

The current COVID-19 pandemic imposes an alarming condition in the world in an unprecedented way. Chronic preexisting metabolic conditions during viral infection increase disease severity and mortality. The altered metabolic environment and impaired immune system reinforced by hypertension, obesity, and diabetes may exacerbate the severity of the disease among infected patients. However, the current understanding of the connection between the triumvirate-hypertension, obesity, and diabetesand related cardiovascular and renal complications with COVID-19 is evolving. Various studies have highlighted the role of ACE2 receptor expression and systemic inflammation in promoting SARS-CoV-2 infection and disease severity. Although several pharmacological interventions for these chronic metabolic disorders also seem to affect ACE2 expression (Fig. 2), it is not clear whether they have any role on the disease severity. Therefore, while research and rapid efforts are being made to develop treatments or vaccines for COVID-19, it is important to identify and investigate alternative clinical treatments that effectively manage the preexisting metabolic perturbations during the COVID-19 pandemic and reduce disease severity. used in these comorbidities (liraglutide for obesity, ACEIs, and ARBs for hypertension and insulin, pioglitazone, and liraglutide for diabetes) have been reported to affect ACE2 expression and hence may affect disease severity.*ARDS, acute respiratory distress syndrome, $A C E I s$, angiotensin-converting enzyme inhibitors, $A R B s$, angiotensin II receptor blockers

Funding No funding was received to assist with the preparation of this manuscript.

\section{Compliance with ethical standards}

Conflict of interest The authors declare that they have no conflict of interest.

\section{References}

1. Center for Systems Science and Engineering (CSSE) at John Hopkins University (JHU) https://gisanddata.maps.arcgis.com/ apps/opsdashboard/index.html\#/bda7594740fd40299423467b4 8e9ecf6. Accessed Aug 52020

2. Ryan DH, Ravussin E, Heymsfield S (2020) COVID 19 and the patient with obesity-the editors speak out. Obesity. https://doi. org/10.1002/oby.22808

3. Feng Y, Ling Y, Bai T et al (2020) COVID-19 with different severities: a multicenter study of clinical features. Am J Respir Crit Care Med 201(11):1380-1388. https://doi.org/10.1164/ rccm.202002-0445OC

4. Chen T, Wu D, Chen $\mathrm{H}$ et al (2020) Clinical characteristics of 113 deceased patients with coronavirus disease 2019: retrospective study. BMJ 368:m1091. https://doi.org/10.1136/bmj. m1091

5. Huang C, Wang Y, Li X et al (2020) Clinical features of patients infected with 2019 novel coronavirus in Wuhan, China. 
Lancet 395(10223):497-506. https://doi.org/10.1016/S0140 $-6736(20) 30183-5$

6. Yang X, Yu Y, Xu J et al (2020) Clinical course and outcomes of critically ill patients with SARS-CoV-2 pneumonia in Wuhan, China: a single-centered, retrospective, observational study. Lancet Respir Med. https://doi.org/10.1016/S2213-2600(20)30079-5

7. Zhou F, Yu T, Du R et al (2020a) Clinical course and risk factors for mortality of adult inpatients with COVID-19 in Wuhan, China: a retrospective cohort study. Lancet. https://doi. org/10.1016/S0140-6736(20)30566-3

8. Richardson S, Hirsch JS, Narasimhan M, Crawford JM, McGinn T, Davidson KW (2020) Presenting characteristics comorbidities and outcomes among 5700 patients hospitalized with COVID19 in the new york city area. JAMA. https://doi.org/10.1001/ jama.2020.6775

9. Petrilli CM, Jones SA, Yang J et al (2020) Factors associated with hospital admission and critical illness among 5279 people with coronavirus disease 2019 in New York City: prospective cohort study. BMJ 369:m1966. https://doi.org/10.1136/bmj.m1966

10. Wang D, Hu B, Hu C et al (2020) Clinical characteristics of 138 hospitalized patients with 2019 novel coronavirus-infected pneumonia in Wuhan, China. JAMA 323(11):1061-1069. https ://doi.org/10.1001/jama.2020.1585

11. Guan W-j, Ni Z-y, Hu Y et al (2020a) Clinical characteristics of coronavirus disease 2019 in China. N Engl J Med 382(18):17081720. https://doi.org/10.1056/NEJMoa2002032

12. Grasselli G, Zangrillo A, Zanella A et al (2020) Baseline characteristics and outcomes of 1591 patients infected with SARSCoV-2 admitted to icus of the Lombardy Region. Italy JAMA 323(16):1574-1581. https://doi.org/10.1001/jama.2020.5394

13. Karlsson EA, Beck MA (2010) The burden of obesity on infectious disease. Exp Biol Med 235(12):1412-1424

14. Masuo K, Tuck ML, Lambert GW (2011) Hypertension and diabetes in obesity. Int J Hypertens. https://doi. org/10.4061/2011/695869

15. Drosten C, Günther S, Preiser W et al (2003a) Identification of a novel coronavirus in patients with severe acute respiratory syndrome. N Engl J Med 348(20):1967-1976

16. Zaki AM, Van Boheemen S, Bestebroer TM, Osterhaus AD, Fouchier RA (2012) Isolation of a novel coronavirus from a man with pneumonia in Saudi Arabia. N Engl J Med 367(19):1814-1820

17. Yang JK, Feng Y, Yuan MY et al (2006a) Plasma glucose levels and diabetes are independent predictors for mortality and morbidity in patients with SARS. Diabet Med 23(6):623-628. https ://doi.org/10.1111/j.1464-5491.2006.01861.x

18. Badawi A, Ryoo SG (2016) Prevalence of comorbidities in the Middle East respiratory syndrome coronavirus (MERS-CoV): a systematic review and meta-analysis. Int J Infect Dis 49:129-133. https://doi.org/10.1016/j.ijid.2016.06.015

19. York I, Donis RO (2012) The 2009 pandemic influenza virus: where did it come from, where is it now, and where is it going? Swine influenza. Springer, Berlin, pp 241-257

20. Karlsson EA, Sheridan PA, Beck MA (2010) Diet-induced obesity impairs the T cell memory response to influenza virus infection. J Immunol 184(6):3127-3133

21. Smith AG, Sheridan PA, Tseng RJ, Sheridan JF, Beck MA (2009) Selective impairment in dendritic cell function and altered antigen-specific CD8+ T-cell responses in diet-induced obese mice infected with influenza virus. Immunology 126(2):268-279

22. Fezeu L, Julia C, Henegar A et al (2011) Obesity is associated with higher risk of intensive care unit admission and death in influenza A (H1N1) patients: a systematic review and metaanalysis. Obes Rev 12(8):653-659
23. Donaldson LJ, Rutter PD, Ellis BM et al (2009) Mortality from pandemic A/H1N1 2009 influenza in England: public health surveillance study. BMJ 339:b5213

24. Van Kerkhove MD, Vandemaele KA et al (2011) Risk factors for severe outcomes following 2009 influenza A (H1N1) infection: a global pooled analysis. PLoS Med 8(7):e1001053

25. Garcia MC, Moros MJS, Peralta PS-O, Hernandez-Barrera V, Jimenez-Garcia R, Pachon I (2012) Clinical characteristics and outcomes of diabetic patients who were hospitalised with 2009 pandemic influenza A H1N1 infection. J Infect 64(2):218-224

26. Valdez R, Narayan K, Geiss LS, Engelgau MM (1999) Impact of diabetes mellitus on mortality associated with pneumonia and influenza among non-Hispanic black and white US adults. Am J Public Health 89(11):1715-1721

27. Jiménez-García R, Hernández-Barrera V, Rodríguez-Rieiro $\mathrm{C}$ et al (2013) Hospitalizations from pandemic Influenza [A (H1N1) pdm09] infections among type 1 and 2 diabetes patients in Spain. Influenza Other Respir Viruses 7(3):439-447

28. Caillon A, Schiffrin EL (2016) Role of inflammation and immunity in hypertension: recent epidemiological, laboratory, and clinical evidence. Curr Hypertens Rep 18(3):21

29. Lee H, Lee IS, Choue R (2013) Obesity, inflammation and diet. Pediatr Gastroenterol Hepatol Nutr 16(3):143-152. https://doi. org/10.5223/pghn.2013.16.3.143

30. Gregor MF, Hotamisligil GS (2011) Inflammatory mechanisms in obesity. Annu Rev Immunol 29:415-445. https://doi. org/10.1146/annurev-immunol-031210-101322

31. Hotamisligil GS (2006) Inflammation and metabolic disorders. Nature 444(7121):860-867. https://doi.org/10.1038/nature0548 5

32. Surmi BK, Hasty AH (2008) Macrophage infiltration into adipose tissue: initiation, propagation and remodeling. Future Lipidol 3(5):545-556. https://doi.org/10.2217/17460875.3.5.545

33. Ferlita S, Yegiazaryan A, Noori N, Lal G et al (2019) Type 2 diabetes mellitus and altered immune system leading to susceptibility to pathogens, especially mycobacterium tuberculosis. J Clin Med 8(12):2219

34. Critchley JA, Carey IM, Harris T, DeWilde S, Hosking FJ, Cook DG (2018) Glycemic control and risk of infections among people with type 1 or type 2 diabetes in a large primary care cohort study. Diab Care 41(10):2127-2135. https://doi.org/10.2337/ dc18-0287

35. Gorbalenya AE, Baker SC, Baric RS et al (2020) The species severe acute respiratory syndrome related coronavirus: classifying 2019-nCoV and naming it SARS-CoV-2. Nat Microbiol 5:536-544

36. Drosten C, Günther S, Preiser W et al (2003b) Identification of a novel coronavirus in patients with severe acute respiratory syndrome. N Engl J Med 348(20):1967-1976. https://doi. org/10.1056/NEJMoa030747

37. Stadler K, Masignani V, Eickmann M et al (2003) SARS—beginning to understand a new virus. Nat Rev Microbiol 1(3):209-218. https://doi.org/10.1038/nrmicro775

38. Zhu N, Zhang D, Wang W et al (2019) Tan W (2020) A novel coronavirus from patients with pneumonia in China. N Engl $\mathrm{J}$ Med 382(8):727-733. https://doi.org/10.1056/NEJMoa2001017

39. Jiang S, Du L, Shi Z (2020) An emerging coronavirus causing pneumonia outbreak in Wuhan, China: calling for developing therapeutic and prophylactic strategies. Emerg Microb Infect 9(1):275-277. https://doi.org/10.1080/22221751.2020.1723441

40. Lu R, Zhao X, Li J et al (2020) Genomic characterisation and epidemiology of 2019 novel coronavirus: implications for virus origins and receptor binding. Lancet 395(10224):565-574. https ://doi.org/10.1016/S0140-6736(20)30251-8 
41. Fehr AR, Perlman S (2015) Coronaviruses: an overview of their replication and pathogenesis. Methods Mol Biol 1282:1-23. https ://doi.org/10.1007/978-1-4939-2438-7_1

42. Hoffmann M, Kleine-Weber H, Schroeder S et al (2020) SARSCoV-2 cell entry depends on ACE2 and TMPRSS2 and is blocked by a clinically proven protease inhibitor. Cell. https:// doi.org/10.1016/j.cell.2020.02.052

43. Walls AC, Park Y-J, Tortorici MA, Wall A, McGuire AT, Veesler D (2020a) Structure, function, and antigenicity of the SARS-CoV-2 spike glycoprotein. Cell. https://doi.org/10.1016/j. cell.2020.02.058

44. Li F (2016) Structure, function, and evolution of coronavirus spike proteins. Ann Rev Virol 3(1):237-261. https://doi. org/10.1146/annurev-virology-110615-042301

45. Letko M, Marzi A, Munster V (2020) Functional assessment of cell entry and receptor usage for SARS-CoV-2 and other lineage B betacoronaviruses. Nat Microbiol 5(4):562-569. https://doi. org/10.1038/s41564-020-0688-y

46. Zhou P, Yang X-L, Wang X-G et al (2020) A pneumonia outbreak associated with a new coronavirus of probable bat origin. Nature 579(7798):270-273. https://doi.org/10.1038/s41586-020-2012-7

47. Wan Y, Shang J, Graham R, Baric RS, Li F (2020) Receptor recognition by the novel coronavirus from Wuhan: an analysis based on decade-long structural studies of SARS coronavirus. J Virol 94(7):e00120-e00127. https://doi.org/10.1128/jvi.00127 $-20$

48. Walls AC, Park Y-J, Tortorici MA, Wall A, McGuire AT, Veesler D (2020b) Structure, function, and antigenicity of the SARSCoV-2 spike glycoprotein. Cell 181(2):281-292.e286. https://doi. org/10.1016/j.cell.2020.02.058

49. Wrapp D, Wang N, Corbett KS et al (2020) Cryo-EM structure of the 2019-nCoV spike in the prefusion conformation. Science 367(6483):1260-1263. https://doi.org/10.1126/science.abb2507

50. Li W, Moore MJ, Vasilieva N et al (2003) Angiotensin-converting enzyme 2 is a functional receptor for the SARS coronavirus. Nature 426(6965):450-454

51. Xiao X, Chakraborti S, DimitrovGramatikoff ASK, Dimitrov DS (2003) The SARS-CoV S glycoprotein: expression and functional characterization. Biochem Biophys Res Commun 312(4):1159-1164

52. Fadason T, Gokuladhas S, Golovina E et al (2020) A transcription regulatory network within the ACE2 locus may promote a proviral environment for SARS-CoV-2 by modulating expression of host factors. bioRxiv. https://doi.org/10.1101/2020.04.14.04200 2

53. Shang J, Wan Y, Luo C et al (2020) Cell entry mechanisms of SARS-CoV-2. Proc Natl Acad Sci 117(21):11727-11734

54. Zhou F, Yu T, Du R et al (2020b) Clinical course and risk factors for mortality of adult inpatients with COVID-19 in Wuhan, China: a retrospective cohort study. Lancet 395(10229):10541062. https://doi.org/10.1016/S0140-6736(20)30566-3

55. Wu C, Chen X, Cai Y et al (2020) Risk factors associated with acute respiratory distress syndrome and death in patients with coronavirus disease 2019 pneumonia in Wuhan, China. JAMA Intern Med. https://doi.org/10.1001/jamainternmed.2020.0994

56. Zhang J-j, Dong X, Cao Y-y et al (2020) Clinical characteristics of 140 patients infected with SARS-CoV-2 in Wuhan, China. Allergy. https://doi.org/10.1111/all.14238

57. McMichael TM, Currie DW, Clark S et al (2020) Epidemiology of Covid-19 in a long-term care facility in King County, Washington. N Engl J Med 382(21):2005-2011

58. Williams B, Mancia G, Spiering W et al (2018) Practice Guidelines for the management of arterial hypertension of the European Society of Hypertension and the European Society of Cardiology: ESH/ESC Task Force for the Management of Arterial Hypertension. J hypertens 36(12):2284-2309
59. Kreutz R, Algharably EAE-H, Azizi M et al (2020) Hypertension, the renin-angiotensin system, and the risk of lower respiratory tract infections and lung injury: implications for COVID-19: European Society of Hypertension COVID-19 Task Force Review of Evidence. Cardiovasc Res. https://doi. org/10.1093/cvr/cvaa097

60. Schiffrin EL, Flack JM, Ito S, Muntner P, Webb RC (2020) Hypertension and COVID-19. Am J Hypertens 33(5):373-374. https://doi.org/10.1093/ajh/hpaa057

61. Ran J, Song Y, Zhuang Z et al (2020) Blood pressure control and adverse outcomes of COVID-19 infection in patients with concomitant hypertension in Wuhan, China. Hypertens Res. https://doi.org/10.1038/s41440-020-00541-w

62. Soler MJ, Barrios C, Oliva R, Batlle D (2008) Pharmacologic modulation of ACE2 expression. Curr Hypertens Rep 10(5):410-414. https://doi.org/10.1007/s11906-008-0076-0

63. Catt KJ, Zimmet PZ, Cain MD, Cran E, Best JB, Coghlan JP (1971) Angiotensin II blood-levels in human hypertension. Lancet 297(7697):459-464. https://doi.org/10.1016/S0140 $-6736(71) 91085-3$

64. Suzuki Y, Ruiz-Ortega M, Lorenzo O, Ruperez M, Esteban V, Egido J (2003) Inflammation and angiotensin II. Int J Biochem Cell Biol 35(6):881-900. https://doi.org/10.1016/S1357 -2725(02)00271-6

65. Benigni A, Cassis P, Remuzzi G (2010) Angiotensin II revisited: new roles in inflammation, immunology and aging. EMBO Mol Med 2(7):247-257. https://doi.org/10.1002/ emmm. 201000080

66. Imai Y, Kuba K, Rao S et al (2005) Angiotensin-converting enzyme 2 protects from severe acute lung failure. Nature 436(7047):112-116. https://doi.org/10.1038/nature03712

67. Kuba K, Imai Y, Rao S et al (2005) A crucial role of angiotensin converting enzyme 2 (ACE2) in SARS coronavirus-induced lung injury. Nat Med 11(8):875-879. https://doi.org/10.1038/nm1267

68. Imai Y, Kuba K, Penninger JM (2008) The discovery of angiotensin-converting enzyme 2 and its role in acute lung injury in mice. Exp Physiol 93(5):543-548. https://doi.org/10.1113/expph ysiol.2007.040048

69. Wu Z, Hu R, Zhang C, Ren W, Yu A, Zhou X (2020a) Elevation of plasma angiotensin II level is a potential pathogenesis for the critically ill COVID-19 patients. Crit Care 24(1):290-290. https ://doi.org/10.1186/s13054-020-03015-0

70. Liu N, Hong Y, Chen R-G, Zhu H-M (2020) High rate of increased level of plasma Angiotensin II and its gender difference in COVID-19: an analysis of 55 hospitalized patients with COVID-19 in a single hospital, WuHan, China. medRxiv. https ://doi.org/10.1101/2020.04.27.20080432

71. Sun ML, Yang JM, Sun YP, Su GH (2020) Inhibitors of RAS might be a good choice for the therapy of COVID-19 Pneumonia. Zhonghua Jie He He Hu Xi Za Zhi 43:E014. https://doi. org/10.3760/cma.j.issn.1001-0939.2020.0014

72. Ferrario CM, Jessup J, Chappell MC et al (2005) Effect of angiotensin-converting enzyme inhibition and angiotensin ii receptor blockers on cardiac angiotensin-converting enzyme 2. Circulation 111(20):2605-2610. https://doi.org/10.1161/CIRCULATIO NAHA.104.510461

73. Ocaranza MP, Godoy I, Jalil JE et al (2006) Enalapril attenuates downregulation of angiotensin-converting enzyme 2 in the late phase of ventricular dysfunction in myocardial infarcted rat. Hypertension 48(4):572-578. https://doi.org/10.1161/01. HYP.0000237862.94083.45

74. Ishiyama Y, Gallagher PE, Averill DB, Tallant EA, Brosnihan KB, Ferrario CM (2004) Upregulation of angiotensin-converting enzyme 2 after myocardial infarction by blockade of angiotensin II receptors. Hypertension 43(5):970-976. https:// doi.org/10.1161/01.HYP.0000124667.34652.1a 
75. Sriram K, Insel PA (2020) A hypothesis for pathobiology and treatment of COVID-19: the centrality of ACE1/ACE2 imbalance. Br J Pharmacol. https://doi.org/10.1111/bph.15082

76. Reynolds HR, Adhikari S, Pulgarin C et al (2020) Renin-angiotensin-aldosterone system inhibitors and risk of Covid-19. N Engl J Med. https://doi.org/10.1056/NEJMoa2008975

77. Fosbøl EL, Butt JH, Østergaard L et al (2020) Association of angiotensin-converting enzyme inhibitor or angiotensin receptor blocker use with COVID-19 diagnosis and mortality. JAMA 324(2):168-177. https://doi.org/10.1001/jama.2020.11301

78. Mancia G, Rea F, Ludergnani M, Apolone G, Corrao G (2020) Renin-Angiotensin-Aldosterone System Blockers and the Risk of Covid-19. N Engl J Med. https://doi.org/10.1056/NEJMo a2006923

79. Vaduganathan M, Vardeny O, Michel T, McMurray JJV, Pfeffer MA, Solomon SD (2020) Renin-Angiotensin-Aldosterone System Inhibitors in Patients with Covid-19. N Engl J Med 382(17):1653-1659. https://doi.org/10.1056/NEJMsr2005760

80. Danser AHJ, Epstein M, Batlle D (2020) Renin-Angiotensin System Blockers and the COVID-19 Pandemic. Hypertension. https://doi.org/10.1161/HYPERTENSIONAHA.120.15082

81. Qingxian C, Fengjuan C, Fang L et al (2020) Obesity and COVID-19 severity in a designated hospital in Shenzhen, China. SSRN J. https://doi.org/10.2139/ssrn.3556658

82. Cai Q, Chen F, Wang T et al (2020) Obesity and COVID19 severity in a designated hospital in Shenzhen, China. Diab Care 43(7):1392-1398. https://doi.org/10.2337/dc20-0576

83. Simonnet A, Chetboun M, Poissy J et al (2020) COVID-19 TLIC, group Os High prevalence of obesity in severe acute respiratory syndrome coronavirus-2 (SARS-CoV-2) requiring invasive mechanical ventilation. Obesity. https://doi. org/10.1002/oby.22831

84. Falagas ME, Kompoti M (2006) Obesity and infection. Lancet Infect Dis 6(7):438-446. https://doi.org/10.1016/s1473 -3099(06)70523-0

85. Heialy SA, Hachim M, Senok A et al (2020) Regulation of angiotensin converting enzyme 2 ACE2 in obesity implications for COVID-19. bioRxiv. https://doi.org/10.1101/2020.04.17.04693 8

86. Belančić A, Kresović A, Rački V (2020) Potential pathophysiological mechanisms leading to increased COVID-19 susceptibility and severity in obesity. Obes Med 19:100259. https://doi. org/10.1016/j.obmed.2020.100259

87. Nuffer WA, Trujillo JM (2015) Liraglutide: a new option for the treatment of obesity. Pharmacother 35(10):926-934. https://doi. org/10.1002/phar.1639

88. Romani-Perez M, Outeirino-Iglesias V, Moya CM, Santisteban P, Gonzalez-Matias LC, Vigo E, Mallo F (2015) Activation of the GLP-1 receptor by liraglutide increases ace 2 expression, reversing right ventricle hypertrophy, and improving the production of sp-a and sp-b in the lungs of type 1 diabetes rats. Endocrinol 156(10):3559-3569. https://doi.org/10.1210/en.2014-1685

89. Brown CV, Neville AL, Rhee P, Salim A, Velmahos GC, Demetriades D (2005) The impact of obesity on the outcomes of 1,153 critically injured blunt trauma patients. J Trauma Acute Care Surg 59(5):1048-1051

90. Anzueto A, Frutos-Vivar F, Esteban A et al (2011) Influence of body mass index on outcome of the mechanically ventilated patients. Thorax 66(1):66-73

91. Jones BH, Standridge MK, Taylor JW, Moustaïd N (1997) Angiotensinogen gene expression in adipose tissue: analysis of obese models and hormonal and nutritional control. Am J Physiol 273(1 Pt 2):R236-242. https://doi.org/10.1152/ajpre gu.1997.273.1.R236

92. Engeli S, Schling P, Gorzelniak K et al (2003) The adipose-tissue renin-angiotensin-aldosterone system: role in the metabolic syndrome? Int J Biochem Cell Biol 35(6):807-825. https://doi. org/10.1016/s1357-2725(02)00311-4

93. Kalupahana NS, Massiera F, Quignard-Boulange A, Ailhaud G, Voy BH, Wasserman DH, Moustaid-Moussa N (2012) Overproduction of angiotensinogen from adipose tissue induces adipose inflammation, glucose intolerance, and insulin resistance. Obesity 20(1):48-56. https://doi.org/10.1038/oby.2011.299

94. Xu Z-G, Lanting L, Vaziri ND, Li Z, Sepassi L, RodriguezIturbe B, Natarajan R (2005) Upregulation of angiotensin II type 1 receptor, inflammatory mediators, and enzymes of arachidonate metabolism in obese zucker rat kidney. Circulation 111(15):1962-1969. https://doi.org/10.1161/01.CIR.0000161831 .07637 .63

95. Wang J, Chen L, Chen B et al (2015) Chronic activation of the renin-angiotensin system induces lung fibrosis. Sci Rep 5(1):15561. https://doi.org/10.1038/srep15561

96. Zhang H, Baker A (2017) Recombinant human ACE2: acing out angiotensin II in ARDS therapy. Crit Care 21(1):305. https://doi. org/10.1186/s13054-017-1882-z

97. Hogue CW, Stearns JD, Colantuoni E, Robinson KA, Stierer T, Mitter N et al (2009) The impact of obesity on outcomes after critical illness: a meta-analysis. Intensive Care Med 35(7):1152

98. Nie W, Zhang Y, Jee SH, Jung KJ, Li B, Xiu Q (2014) Obesity survival paradox in pneumonia: a meta-analysis. BMC Medicine 12(1):61. https://doi.org/10.1186/1741-7015-12-61

99. Fernandez-Bustamante A, Repine J (2013) Adipose-lung cell crosstalk in the obesity-ARDS paradox. J Pulm Respir Med 3:144

100. Jose RJ, Manuel A (2020) Does Coronavirus Disease 2019 Disprove the Obesity Paradox in Acute Respiratory Distress Syndrome? Obesity (Silver Spring) 28(6):1007-1007. https://doi. org/10.1002/oby.22835

101. Shi S, Qin M, Shen B et al (2020a) Association of cardiac injury with mortality in hospitalized patients with COVID-19 in Wuhan, China. JAMA Cardiol. https://doi.org/10.1001/jamac ardio.2020.0950

102. Bean D, Kraljevic Z, Searle T et al (2020) Treatment with ACEinhibitors is associated with less severe disease with SARSCovid-19 infection in a multi-site UK acute Hospital Trust. medRxiv. https://doi.org/10.1101/2020.04.07.20056788

103. Yang J, Feng Y, Yuan M et al (2006b) Plasma glucose levels and diabetes are independent predictors for mortality and morbidity in patients with SARS. Diabet Med 23(6):623-628

104. Yang J-K, Jin J-M, Liu S, Bai P, He W, Wu F et al (2020) Blood glucose is a representative of the clustered indicators of multiorgan injury for predicting mortality of COVID-19 in Wuhan, China. medRxiv. https://doi.org/10.1101/2020.04.08.20058040

105. Bode B, Garrett V, Messler J et al (2020) Glycemic characteristics and clinical outcomes of COVID-19 patients hospitalized in the United States. J Diab Sci Technol. https://doi.org/10.1177/19322 96820924469

106. Zhu L, She Z-G, Cheng X et al (2020) Association of blood glucose control and outcomes in patients with Covid-19 and preexisting type 2 diabetes. Cell Metab. https://doi.org/10.1016/j. cmet.2020.04.021

107. Roncon L, Zuin M, Rigatelli G, Zuliani G (2020) Diabetic patients with COVID-19 infection are at higher risk of ICU admission and poor short-term outcome. J Clin Virol 127:104354-104354. https://doi.org/10.1016/j.jcv.2020.104354

108. Forbes A, Murrells T, Mulnier H, Sinclair AJ (2018) Mean $\mathrm{HbA1c}, \mathrm{HbA1c}$ variability, and mortality in people with diabetes aged 70 years and older: a retrospective cohort study. Lancet Diab Endocrinol 6(6):476-486

109. Roca-Ho H, Riera M, Palau V, Pascual J, Soler MJ (2017) Characterization of ACE and ACE2 expression within different organs of the NOD mouse. Int J Mol Sci. https://doi. org/10.3390/ijms18030563 
110. Wysocki J, Ye M, Soler MJ et al (2006) ACE and ACE2 activity in diabetic mice. Diabetes 55(7):2132-2139. https://doi. org/10.2337/db06-0033

111. Rao S, Lau A, So HC (2020) Exploring diseases/traits and blood proteins causally related to expression of ACE2, the putative receptor of SARS-COV-2: a mendelian randomization analysis highlights tentative relevance of diabetes-related traits. Diab Care. https://doi.org/10.2337/dc20-0643

112. Zhang W, Xu YZ, Liu B et al (2014) Pioglitazone upregulates angiotensin converting enzyme 2 expression in insulinsensitive tissues in rats with high-fat diet-induced nonalcoholic steatohepatitis. Sci World J 2014:603409. https://doi. org/10.1155/2014/603409

113. Bestle D, Heindl MR, Limburg H et al (2020) TMPRSS2 and furin are both essential for proteolytic activation and spread of SARS-CoV-2 in human airway epithelial cells and provide promising drug targets. bioRxiv. https://doi. org/10.1101/2020.04.15.042085

114. Fernandez C, Rysa J, Almgren P et al (2018) Plasma levels of the proprotein convertase furin and incidence of diabetes and mortality. J Intern Med 284(4):377-387. https://doi. org/10.1111/joim. 12783

115. Chen $X, \mathrm{Hu}$ W, Ling $\mathrm{J}$ et al (2020) Hypertension and diabetes delay the viral clearance in COVID-19 patients. medRxiv. https ://doi.org/10.1101/2020.03.22.20040774

116. Sardu C, D’Onofrio N, Balestrieri ML et al (2020) Outcomes in patients with hyperglycemia affected by Covid-19: can we do more on glycemic control? Diab Care. https://doi.org/10.2337/ dc20-0723

117. Li J, Wang X, Chen J, Zuo X, Zhang H, Deng A (2020) COVID-19 infection may cause ketosis and ketoacidosis. Diab, Obes Metab 22(10):1935-1941

118. Rayman G, Lumb A, Kennon B et al (2020) Guidance on the management of Diabetic Ketoacidosis in the exceptional circumstances of the COVID-19 pandemic. Diab Med 37(7):1214-1216

119. Cariou B, Hadjadj S, Wargny M et al (2020) Phenotypic characteristics and prognosis of inpatients with COVID-19 and diabetes: the CORONADO study. Diabetologia 63:1500-1515. https ://doi.org/10.1007/s00125-020-05180-x

120. Rubino F, Amiel SA, Zimmet P et al (2020) New-onset diabetes in Covid-19. N Engl J Med. https://doi.org/10.1056/NEJMc 2018688

121. Hamming I, Timens W, Bulthuis MLC, Lely AT, Navis GJ, van Goor H (2004) Tissue distribution of ACE2 protein, the functional receptor for SARS coronavirus. A first step in understanding SARS pathogenesis. J Pathol 203(2):631-637. https://doi. org/10.1002/path.1570

122. Yang L, Han Y, Nilsson-Payant BE et al (2020) A human pluripotent stem cell-based platform to study sars-cov-2 tropism and model virus infection in human cells and organoids. Cell Stem Cell 27(1):125-136.e127. https://doi.org/10.1016/j. stem.2020.06.015

123. Yang J-K, Lin S-S, Ji X-J, Guo L-M (2010) Binding of SARS coronavirus to its receptor damages islets and causes acute diabetes. Acta Diabetol 47(3):193-199

124. Hadi A, Werge M, Kristiansen KT et al (2020) Coronavirus disease-19 (COVID-19) associated with severe acute pancreatitis: case report on three family members. Pancreatology 20(4):665667. https://doi.org/10.1016/j.pan.2020.04.021

125. Wang F, Wang H, Fan J, Zhang Y, Wang H, Zhao Q (2020) Pancreatic injury patterns in patients with coronavirus disease 19 pneumonia. Gastroenterol 159(1):367-370. https://doi. org/10.1053/j.gastro.2020.03.055
126. Aloysius MM, Thatti A, Gupta A, Sharma N, Bansal P, Goyal H (2020) COVID-19 presenting as acute pancreatitis. Pancreatology. https://doi.org/10.1016/j.pan.2020.05.003

127. Mehta P, McAuley DF, Brown M, Sanchez E, Tattersall RS, Manson JJ (2020) COVID-19: consider cytokine storm syndromes and immunosuppression. Lancet 395(10229):1033-1034. https://doi.org/10.1016/S0140-6736(20)30628-0

128. Cheng Y, Luo R, Wang $\mathrm{K}$ et al (2020) Kidney disease is associated with in-hospital death of patients with COVID-19. Kidney Int 97(5):829-838. https://doi.org/10.1016/j.kint.2020.03.005

129. Wu J, Li J, Zhu G, Zhang Y, Bi Z, Yu Y, Huang B, Fu S, Tan Y, Sun J, Li X (2020) Clinical features of maintenance hemodialysis patients with 2019 novel coronavirus-infected pneumonia in Wuhan, China. Clin J Am Soc Nephrol 15(8):1139-1145. https ://doi.org/10.2215/cjn.04160320

130. Virani SS, Alonso A, Benjamin EJ et al (2020) Heart disease and stroke statistics 2020 update: a report from the American heart association. Circulation. https://doi.org/10.1161/CIR.00000 00000000757

131. He J, Whelton PK (1999) Elevated systolic blood pressure and risk of cardiovascular and renal disease: overview of evidence from observational epidemiologic studies and randomized controlled trials. Am Heart J 138(3 Pt 2):211-219. https://doi. org/10.1016/s0002-8703(99)70312-1

132. Stamler J, Stamler R, Neaton JD (1993) Blood pressure, systolic and diastolic, and cardiovascular risks. US Popul Data Arch Intern Med 153(5):598-615. https://doi.org/10.1001/archi nte.153.5.598

133. Zheng Y-Y, Ma Y-T, Zhang J-Y, Xie X (2020) COVID-19 and the cardiovascular system. Nat Rev Cardiol 17(5):259-260

134. Driggin E, Madhavan MV, Bikdeli B et al (2020) Cardiovascular considerations for patients, health care workers, and health systems during the COVID-19 pandemic. J Am Coll Cardiol 75(18):2352-2371

135. Guan W-j, Ni Z-y, Hu Y et al (2020b) Clinical characteristics of coronavirus disease 2019 in China. N Engl J Med 382(18): 1708-1720

136. Clerkin KJ, Fried JA, Raikhelkar J et al (2020) COVID-19 and cardiovascular disease. Circulation 141(20):1648-1655

137. Madjid M, Safavi-Naeini P, Solomon SD, Vardeny O (2020) Potential effects of coronaviruses on the cardiovascular system: a review. JAMA Cardiol. https://doi.org/10.1001/jamacardio .2020 .1286

138. Wu Z, McGoogan JM (2020) Characteristics of and important lessons from the coronavirus disease 2019 (COVID-19) outbreak in China: summary of a report of 72314 cases from the Chinese Center for Disease Control and Prevention. JAMA 323(13):1239-1242

139. Shi S, Qin M, Cai Y et al (2020) Characteristics and clinical significance of myocardial injury in patients with severe coronavirus disease 2019. Eur Heart J 41(22):2070-2079

140. Shi S, Qin M, Shen B et al (2020b) Association of cardiac injury with mortality in hospitalized patients with COVID-19 in Wuhan, China. JAMA Cardiol 5(7):802

141. Guo T, Fan Y, Chen M et al (2020b) Cardiovascular implications of fatal outcomes of patients with coronavirus disease 2019 (COVID-19). JAMA Cardiol 5(7):811-818. https://doi. org/10.1001/jamacardio.2020.1017

142. Gavras I, Gavras H (2002) Angiotensin II as a cardiovascular risk factor. J Hum Hypertens 16(2):S2-S6. https://doi.org/10.1038/ sj.jhh.1001392

143. Zablocki D, Sadoshima J (2013) Angiotensin II and oxidative stress in the failing heart. Antioxid Redox Signal 19(10):10951109. https://doi.org/10.1089/ars.2012.4588 
144. Berbudi A, Rahmadika N, Tjahjadi AI, Ruslami R (2020) Type 2 diabetes and its impact on the immune system. Curr Diabetes Rev 16(5):442-449. https://doi.org/10.2174/157339981566619 1024085838

145. Toniolo A, Cassani G, Puggioni A et al (2019) The diabetes pandemic and associated infections: suggestions for clinical microbiology. Rev Med Microbiol 30(1):1-17. https://doi.org/10.1097/ mrm.0000000000000155

146. Wang L, Li X, Chen $\mathrm{H}$ et al (2020) Coronavirus disease 19 infection does not result in acute kidney injury: an analysis of 116 hospitalized patients from Wuhan, China. Am J Nephrol 51(5):343-348. https://doi.org/10.1159/000507471

147. Hong X-W, Chi Z-P, Liu G-Y et al (2020) Characteristics of renal function in patients diagnosed with covid-19: an observational study. Front Med. https://doi.org/10.3389/fmed.2020.00409

148. Pei G, Zhang Z, Peng J et al (2020) Renal involvement and early prognosis in patients with COVID-19 pneumonia. J Am Soc Nephrol 31(6):1157-1165. https://doi.org/10.1681/asn.20200 30276

149. Hirsch JS, Ng JH, Ross DW et al (2020) Acute kidney injury in patients hospitalized with COVID-19. Kidney Int 98(1):209-218. https://doi.org/10.1016/j.kint.2020.05.006
150. Mohamed MMB, Lukitsch I, Torres-Ortiz AE et al (2020) Acute kidney injury associated with coronavirus disease 2019 in urban New Orleans. Kidney360. https://doi.org/10.34067/kid.00026 52020

151. Du M, Cai G, Chen F, Christiani DC, Zhang Z, Wang M (2020) Multiomics evaluation of gastrointestinal and other clinical characteristics of COVID-19. Gastroenterology 158(8):2298-2301. https://doi.org/10.1053/j.gastro.2020.03.045

152. Varga Z, Flammer AJ, Steiger P et al (2020) Endothelial cell infection and endotheliitis in COVID-19. Lancet 395(10234):1417-1418. https://doi.org/10.1016/s0140 $-6736(20) 30937-5$

153. Puelles VG, Lütgehetmann M, Lindenmeyer MT et al (2020) Multiorgan and renal tropism of SARS-CoV-2. N Engl J Med. https://doi.org/10.1056/nejmc2011400

Publisher's Note Springer Nature remains neutral with regard to jurisdictional claims in published maps and institutional affiliations. 